\title{
APPENDIX \\ III. GASEOUS AND HEAVY HYDROCARBONS IN CANNED CORE SAMPLES FROM LEG 24, DSDP
}

Richard D. McIver, Esso Production Research Company, Houston, Texas

\section{INTRODUCTION}

Nine canned core samples from Sites 231 and 232 were analyzed by organic geochemical techniques as part of our continuing program to characterize the properties of Deep Sea Drilling Project samples. The total gas in the containers were determined first, by techniques reported earlier (McIver, 1973), then total organic carbon was run. Because of the high organic carbon contents, some of the samples were next extracted with organic solvents to remove soluble organic matter, bitumens, for subsequent separation and identification (by techniques reported by Gehman, 1962, and Koons and Monaghan, 1960). Another portion was treated with $\mathrm{HF}$ and the insoluble organic matter separated and described by methods similar to those reported by Staplin (1969).

Table 1 lists the data on the samples. Figure 1 shows, in histogram form, how the total residual gas contents compare with contents of previously run DSDP samples, and Figure 2 shows how the ratio of gas to organic carbon also compares with them.

\section{DISCUSSION}

The four upper Pliocene samples from Site 231, from the Southern Gulf of Aden off Somalia, are rich in organic carbon, and three of them are moderately rich in hydrocarbon gas, virtually all of which is methane. Figures 1 and 2 show that, compared to samples run previously (Legs 18 through 23), these samples are not unusual either in gas content or in gas per unit volume of organic carbon. They are not quite as rich in gas as the samples from the Red Sea (McIver, in press) cored during the preceding leg. The five upper Miocene to lower Pliocene samples from Site 232, from the extreme Northeast Gulf of Aden, near the western edge of the Alula-Fartak Trench, off Saudi Arabia are also above average in organic carbon for deep-sea samples and run about half the organic carbon contents and half the gas contents on the average as samples from Site 231.

The high organic contents certainly suggest that the young sediments have high potential for generating hydrocarbons in the future. The moderately high bitumen contents (177 to $590 \mathrm{ppm}$ ) and the high bitumen to carbon ratios suggest future oil source potential, much like the Leg 23 samples. The ratios of hydrocarbon to bitumen $(0.11$ to 0.21 ) are next to the highest (from the Red Sea) we have seen to date; this indicates they are liquid-hydrocarbon prone and the the process of conversion of bitumens to liquid hydrocarbon or kerogen to liquid hydrocarbon has begun. However, the visual estimates of extent of alteration of the kerogen indicate that the process has only just started, at least in the samples we analyzed. The two deeper, more organic-rich samples from Site 231 would be classified as a marginal potential active source of oil because

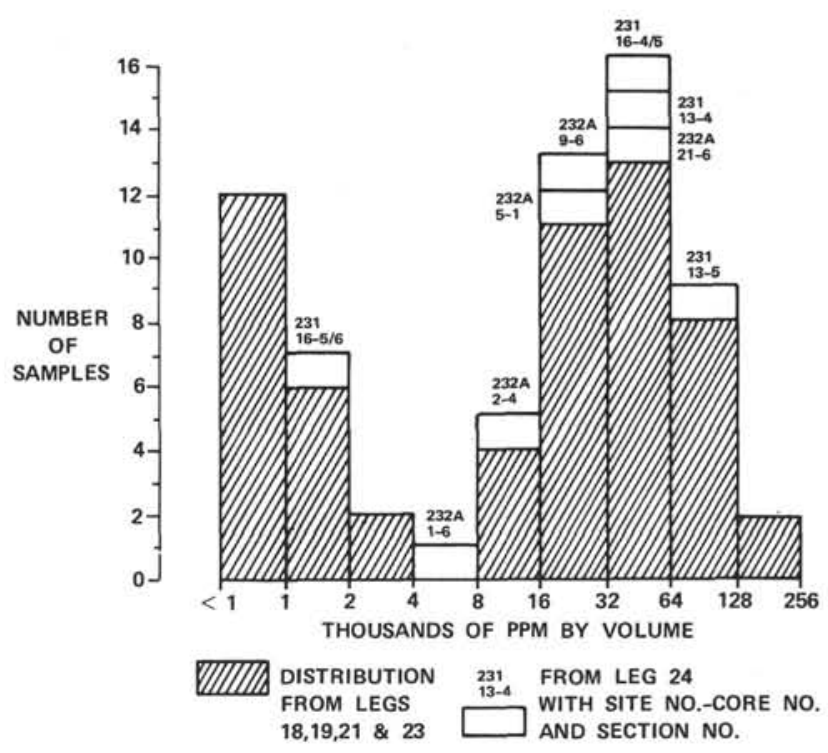

Figure 1. Range of residual gas contents of Leg 24 canned core samples compared with results from previous DSDP samples.

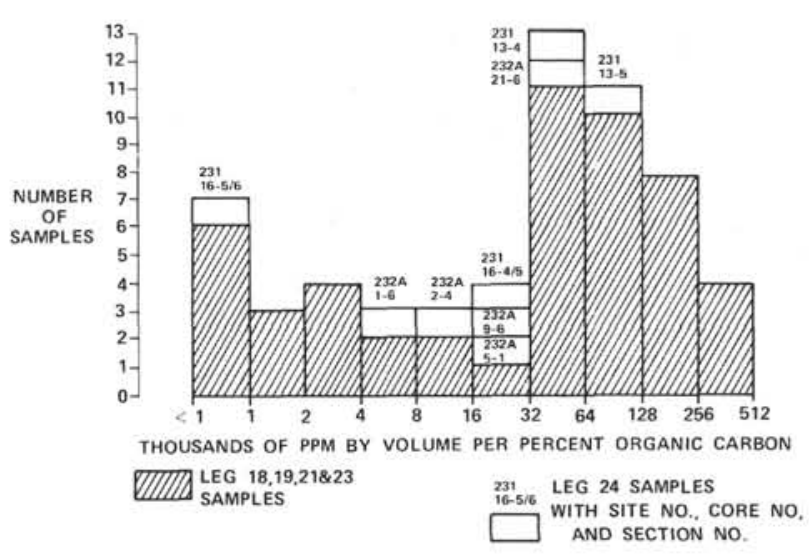

Figure 2. Range of ratios of residual gas to organic carbon contents of Leg 24 canned cores versus previously run DSDP samples.

of their organic carbon $(2.1 \%$ and $2.2 \%)$ and $\mathrm{C}_{15^{+}}$ hydrocarbon (113 and $65 \mathrm{ppm}$ ) contents according to published criteria (Philippi, 1956).

In conclusion, these nine samples indicate that the environment of deposition that prevailed in the Western Gulf of Aden from the upper Miocene through the upper Pliocene was conducive to the deposition and preservation or organic-rich rocks that has good potential for oil and gas generation should they be exposed to higher temperatures, 
TABLE 1

Results of Analyses of Leg 24 Canned Core Samples

\begin{tabular}{|c|c|c|c|c|c|c|c|c|c|c|}
\hline Sample & $\begin{array}{c}\text { DSDP } \\
\text { Site }\end{array}$ & $\begin{array}{l}\text { Core } \\
\text { Core }\end{array}$ & Section & $\begin{array}{l}\text { Water } \\
\text { Depth } \\
\text { (m) }\end{array}$ & $\begin{array}{l}\text { Depth } \\
\text { Below } \\
\text { Mudline } \\
\text { (m) }\end{array}$ & $\begin{array}{l}\text { Organic } \\
\text { Carbon } \\
\text { (wt \%) }\end{array}$ & $\begin{array}{l}\text { Methane } \\
\text { (PPM by } \\
\text { Volume) }\end{array}$ & $\begin{array}{l}\text { Solvent-Soluble } \\
\text { Bitumens } \\
\text { (PPM by wt) }\end{array}$ & $\begin{array}{c}\mathrm{C}_{15^{+}} \\
\text {Hydrocarbons } \\
\text { (PPM by wt) }\end{array}$ & $\begin{array}{c}\mathrm{C}_{15^{+}} \\
\text {Sat/Arom } \\
\text { Ratio }\end{array}$ \\
\hline 1 & 231 & 13 & $4-?$ & 2161 & 105 & 1.1 & 41,900 & 258 & 48 & 0.55 \\
\hline 2 & 231 & 13 & $5-?$ & 2161 & 106 & 1.5 & 67,000 & 247 & 44 & 0.39 \\
\hline 3 & 231 & 16 & $4 / 5$ & 2161 & 136 & 2.1 & 62,600 & 525 & 113 & 0.25 \\
\hline 4 & 231 & 16 & $5 / 6$ & 2161 & 138 & 2.2 & 1,300 & 590 & 65 & 0.36 \\
\hline 5 & 232 & 1 & $6-15 \mathrm{~cm}$ & 1758 & 167 & 1.1 & 7,600 & 286 & 43 & 0.65 \\
\hline 6 & 232 & 2 & 4-btm & 1758 & 175 & 1.0 & 12,400 & 282 & 51 & 0.41 \\
\hline 7 & 232 & 5 & $1-5 \mathrm{~cm}$ & 1758 & 197 & 0.8 & 18,600 & 268 & 45 & 1.47 \\
\hline 8 & 232 & 9 & $6-15 \mathrm{~cm}$ & 1758 & 243 & 1.0 & 29,000 & 177 & 37 & 1.24 \\
\hline 9 & 232 & 21 & $6-15 \mathrm{~cm}$ & 1758 & 356 & 1.0 & 34,100 & 282 & 49 & 0.50 \\
\hline
\end{tabular}

Visual Description of Insoluble Organic Matter

\begin{tabular}{cccccc}
\hline Sample & Primary Type & Secondary Type & $\begin{array}{c}\text { State of } \\
\text { Preservation }\end{array}$ & $\begin{array}{c}\text { Alteration } \\
1-\text { Unaltered } \\
5-\text { Carbonized }\end{array}$ & Shipboard Description \\
\hline 1 & Amorphous & Woody & Very poor & 1 & $\begin{array}{l}\text { Lt. olive gray nanno chalk mud with } \\
\text { sand-filled burrows }\end{array}$ \\
2 & Amorphous/woody & - & Very poor & 1 & Lt. olive gray nanno chalk mud \\
3 & Amorphous & Woody & Very poor & $1-2$ & Lt. olive gray nanno chalk mud \\
4 & Amorphous & Woody & Very poor & $1-2$ & Lt. olive gray nanno chalk mud \\
5 & & & & & Dusky yellow-green nanno chalk mud \\
6 & & & & & Dusky yellow-green nanno chalk mud \\
7 & & & & Dusky yellow-green nanno chalk mud \\
8 & & & & Olive gray nanno chalk mud \\
9 & & & & Dusky yellow-green nanno chalk mud \\
\hline
\end{tabular}

or perhaps current ones for much longer periods of time. At present, they are too unaltered thermally to act as sources of significant quantities of oil and gas.

\section{ACKNOWLEDGMENTS}

The author thanks Ralph Pokluda, Harvey Fry, Jim Morgan, and Shirley Tillotson who made this work possible with their assistance in the laboratory and Esso Production Research Company for their continuing support of this work and for their permission to prepare and publish this report.

\section{REFERENCES}

Gehman, H. M., Jr., 1962. Organic matter in limestones; Geochim. Cosmochim. Acta, v. 26, p. 885.

Koons, C. B. and Monaghan, P. H., 1969. Data and discussion of analyses, including $\mathrm{C}^{12} / \mathrm{C}^{13}$ ratios. In Ewing, M. W. et al., Initial Reports of the Deep Sea Drilling
Project, Volume I: Washington (U. S. Government Printing Office), p. 478.

McIver, R. D., 1973. Hydrocarbon gases from canned core samples, Sites $174 \mathrm{~A}, 176$ and 180 . In von Huene, et al., Initial Reports of the Deep Sea Drilling Project, Volume 18: Washington (U.S. Government Printing Office), p. 1013.

in press. Residual gas contents of organic-rich canned sediment samples from Leg 23. In Whitmarsh, R. B., Weser, O.E., and Ross, D. A., et al., Initial Reports of the Deep Sea Drilling Project, Volume 23: Washington (U.S. Government Printing Office).

Philippi, G. T., 1956. Identification of oil source beds by chemical means: 29th Intern. Geol. Congr., Mexico, 1956, Report 25.

Staplin, F. L., 1969. Sedimentary organic matter, organic metamorphism and oil and gas occurrence: Geol. Bull., Canadian Petrol., v. 17, p. 47. 